\title{
CONSIDERATIONS ON THE IMPACT OF EMERGING AND DISRUPTIVE TECHNOLOGIES ON SECURITY POLICIES
}

\author{
Mircea VLADU \\ vladumircea57@yahoo.com \\ Stelian POPESCU \\ fam_popes@yahoo.com
}

“NICOLAE BĂLCESCU” LAND FORCES ACADEMY, SIBIU, ROMANIA

\begin{abstract}
The issue of the impact of emerging and disruptive technologies on security policy is a major concern of the North Atlantic Treaty Alliance. This is also demonstrated by the meeting between the Board members and the newly-established Advisory Group for Emerging and Disruptive Technologies, consisting of top experts in the fields of Cyber, Artificial Intelligence, Quantum Computing, Big Data, Space, Robotics and Autonomous or Biotechnological Systems, to find new synergies between NATO, the private, governmental and academic sectors and to maintain the technological supremacy of the Alliance. At the same time, the fact that the Romanian Army has mastered the defining elements of the impact of emerging and disrupted technologies on security policy and acts to make them operational is demonstrated by the meeting of July 12, 2021, of the Minister of National Defense, Nicolae-Ionel Ciuca with Heidi Grant, director of the US Defense and Security Cooperation Agency, on which occasion Romania received from the US the name of "Dependable Undertaking (DU)" under which contracts for the purchase of military equipment can be concluded without any payment in advance. Based on these elements, we would like to continue to talk about some aspects of innovation in dual military technologies, such as the influence of emerging and disruptive technologies on the organization and use of the armed forces. The research method undertaken consisted in identifying bibliographic resources, studying them, drawing relevant conclusions and formulating points of view on the impact of emerging and disruptive technologies on security policies.
\end{abstract}

\section{KEYWORDS:}

Autonomous lethal weapons, biotechnology, disruptive technologies, hypersonic weapon, military applications

\section{Introduction}

The new defense dictionary has a multitude of technical terms generated by the fourth industrial revolution, which influences the concept of security (Iancu, 2019).
The process of merging thirdgeneration technologies has led to the blurring of the boundaries of the cognitive and application areas of some niche domains, by integrative solutions aimed at 
fundamental changes in the way human resources currently act and interact.

Debates on political and security developments in Munich and Davos, as well as in G.7 or G.20, highlighted the fact that in the near future disruptive military technologies with significant influences on international security will be represented by: artificial intelligence; autonomous weapons systems; hypersonic weapons; directed weapons; quantum technology; biotechnology (Iancu, 2019).

Some aspects related to disruptive technologies with military applications will be presented below.

\section{Disruptive technologies with military applications}

Disruptive military technology can be seen as an improved technology or a new technology that can bring about a fundamental change in traditional security and defense models aimed at (Iancu, 2019):

a) redefining classical security strategies;

b) changing military doctrines;

c) changing the organizational solutions for the defense institutions;

d) adapting the concepts of operations or even the logistics of the war of the future;

e) changing paradigms in international relations and security studies.

Realistic thinking about disruptive military technologies requires state entities to seriously consider the following elements:

- power - is the central unit for analyzing the security behavior of states within the international system and is found in the volume and complexity of military capabilities that a state has;

- the significant military capacity of the state that cannot be ensured without sufficient economic, financial, technological and demographic resources.

Realistic thinking must start from the idea that the primary conditions for the accumulation of the aforementioned resources have remained unchanged since the emergence of the state as a politicaladministrative entity and cover the area of national territory or controlled by a particular state and its population size.

The new technologies owned by certain states will give them the opportunity to dominate the world, excluding their dependence on geography and demography. From this perspective, new weapons can be deployed and redeployed anywhere and anytime on the surface of the globe, making geography insignificant from this point of view. It should also be noted that future military capabilities will have a high potential for analysis and self-learning, based on which they can make complex decisions that can decide the fate of conflicts, without involving a large number of military and civilians, as is currently happening. Military experts believe that artificial intelligence represented by a machine capable of imitating the cognitive functions, conventionally associated with humans and creating human knowledge is at the heart of these developments must be (Iancu, 2019).

ISR and C2 systems, semi-autonomous and autonomous vehicles, cyber operations, intelligence logistics, etc. are already the result of the use of artificial intelligence.

The future offers the opportunity to increase the level of integration of these systems for coordination in order to fulfill the most complex missions, although security discourses seek to reduce trust and public support for defense efforts, as well as blackmail and manipulation, while opponents are concerned with using their own artificial intelligence for the configuration of the operational field and with generating false intelligence reports on the situation on the ground (Iancu, 2019).

From ancient times the war has benefited from measures aimed at inducing false perceptions, but artificial intelligence will cause the forms and methods of inducing false perceptions to become 
extremely sophisticated and therefore difficult to counter.

A category of weapons capable of identifying, engaging and destroying targets without human intervention is represented by autonomous lethal weapons, based on advanced systems of calculation, analysis and decision, sets of weapons for observing, identifying and classifying an object as being hostile, as well as on equipment to guide the lethal target vector, whose autonomy would allow for functioning in operational environments, hostile to the means of communication, command and remote control, only that, so far, such weapons have not reached the endowment of the armies, as it has not been possible to fine-tune the issue of employment and destruction of targets in the absence of the analytical filter of human decision, in the conditions of strict observance of the rules of engagement in operations, as well as the laws of war.

The hypersonic weapon is under consideration for operationalization, both in Moscow and in the United States, China, France, Germany, Australia and India. The hypersonic weapon is expected to exceed five times the speed of sound in flight, and some fighter jets three times the speed of sound.

The following hypersonic categories are targeted:

a) aerodynamic hypersonic vehicles carried by ballistic missiles launched from outer space, with advanced aerodynamic properties that allow them to slide back to the ground along winding trajectories, difficult to intercept, sometimes with speeds even higher than 20 Mach;

b) hypersonic cruise missiles usually launched from aircraft, equipped with rocket engines capable of imprinting hypersonic speeds along their entire length. An example of such a missile is the one declared by Russia, under the name of $\mathrm{Kh}-47 \mathrm{M} 2 \mathrm{Kinzhal}$, which is supposed to have a range of $3,000 \mathrm{~km}$, given the flight range of the carrier aircraft, if launched from the supersonic bomber $\mathrm{Tu}-22 \mathrm{M} 3$ and a range of $2,000 \mathrm{~km}$ if launched from the MIG-31K fighter jet, with which the first tests were performed (Iancu, 2019).

Preferred targets are: aircraft carriers; cruisers; destroyers; frigates etc.

Russia says it has aerodynamic hypersonic aircraft, such as the Avangard $\mathrm{HGV}$, which at a speed of 6,000 kilometers reached a speed of $33,000 \mathrm{~km} / \mathrm{h}$. Russia also said it had successfully tested its new Zircon hypersonic cruise missile, which is part of the arsenal developed by this military superpower, and some specialists affirm that this missile is unmatched in the world (Huza, 2021). This statement belonged to the Russian Ministry of Defense, according to Nevs.ro, which stated that the "Admiral Gorchkov" Frigate launched a hypersonic Zircon rocket from the White Sea to a ground target on the Barents Sea coast, the rocket flying at Mach 7 successfully hitting the $350 \mathrm{~km}$ away target.

It should be noted that the first official launch of a Zircon rocket took place in October 2020, on which occasion President Vladimir Putin appreciated the launch as a major event for the whole of Russia. After that launch, at least two more tests were made on the "Admiral Gorchkov" Frigate. Russia also has the Kinjal hypersonic missile for the Air Force and the Bourevestnik nuclear missile (Huza, 2021).

The advance taken by Russia and China on the issue of hypersonic weapons has led the Pentagon to declare that the US also considersthe development of hypersonic weapons, with the help of the Lockheed Martin Company a priority. It runs several budgeted programs, as follows: Tactical Boost Glide Vehicle, Hypersonic Conventional Strike Weapon and Arrow for the Air Force; Intermediate-Range Conventional Strike Weapon System for the naval forces. There are other American companies engaged in hypersonic weapons development programs such as Boeing and Raytheon or the consortium of Aerojet Rocketdyne, Sierra 
Nevada Corporation and Exquadrum formed under the auspices of the Op Fire program.

Hypersonic weapons are clearly different from ballistic missiles by the very high speeds that can be reached, as well as by their maneuverability, which makes them difficult to intercept by anti-aircraft and anti-missile defense systems.

Targeted energy weapon systems, located on fixed or mobile platforms, could be designed to enter the armed forces in order to combat missiles, artillery shells, grenade launchers, as well as close air defense, thus replacing the kinetic means that are being currently used. An example of such targeted energy weapons is the 30 Kw Laws Naval System, already used by the US Naval Forces in the Persian Gulf, a system that costs $\$ 40$ million, while a blow costs only $\$ 1$. It is worth noting that the ammunition support of the system is expected to be unlimited, the accuracy of the system being much better than that of any existing kinetic system, while the speed of the shot must be equal to that of light. For example, Lockheed Martin developed the Helios System (High Energy Laser and Integrated Optical-dazzler with Surveillance) with a budget of $\$ 150$ million, which led to the operationalization of a laser weapon with a power between 60 and $150 \mathrm{KW}$, in the year 2020 (Iancu, 2019).

High-power microwave weapons were made long ago using non-lethal electromagnetic pulses in order to be used to control large groups of people participating in large-scale demonstrations that degenerated into violence (Iancu, 2019). As their use was considered to generate heated discussions domestically and internationally, they were not used. In the new constructive and functional formula, these weapons have acquired a new destination aimed at annihilating improvised explosive devices, as well as electronic equipment and communication, command and control systems.

Quantum technology in the prototype development stage (Iancu, 2019) is considered as one of the important achievements that, when operationalized, will increase the performance of quantum computers so that they will be able to reduce the decryption time of a very complicated code from years to that measured in minutes or even seconds. Also, quantum radars will be able to locate targets with great precision, exceeding the performance of conventional systems. If currently invisible or small radar fighter and bombers aircraft are difficult to detect, quantum technology will make them visible, the same performance being obtained for submarines.

Biotechnology that aims at, among other things, genetic modification and DNA creation can be applied to improve or reduce the performance of fighters, as well as the development of genetic codes that do not exist in nature so far, leading to the improvement and even to the development of new chemical and biological weapons (Iancu, 2019). In other words, biotechnology capitalizes on knowledge from the life sciences to ensure the development of new technologies, some with major implications for national security.

Technologies for increasing human performance aim to increase the performance of fighters by gaining an advantage activating human senses to extremes, namely human mental and physical abilities, using implants, mechanical or computational systems with intrusive and non-intrusive uses in relation to the human body (Iancu, Dănilă, Oprea, Eremia, \& Dincovici, 2020).

Directed Energy Weapons (SAEDs) are weapons systems that also use electromagnetic energy. Prototypes of such weapons with energy pulses were made and tested in missile combat missions, artillery shells, grenade launchers, as well as to ensure close air defense. From this perspective, laser ammunition can replace the kinetic means that are currently used at very low costs (Iancu et al., 2020). 
In the category of laser ammunition electric lasers and high power microwave weapons are found. Electrolasers use the plasma beam to transmit electric shocks to the target, thus removing man and electronic equipment from action. High power microwave weapons are used to decommission electronic equipment and communications, command and control systems, as well as improvised explosive devices (Eremia \& Negoiță, 2021).

\section{Military and dual technologies}

There are new areas of competition between the USA and China, among which the cyber one takes priority. From this perspective, we can mention the Blockchain technology on which Chinese military specialists have focused their efforts in different manners, raising the concerns of American analytical circles, which do not welcome Beijing's efforts to achieve this technology. They are of the opinion that this will make China a world leader in this technology and consider that a "blockchain" strategy must be adopted and implemented (Eremia \& Negoiţă, 2021).

$3 \mathrm{D}$ printing technology has also recently entered the military for the production of spare parts and accessories, thus reducing the dependence of logistics structures on external suppliers of spare parts, as well as for the execution of military infrastructure elements such as barracks and storage spaces (Iancu et al., 2020).

The military Internet of Things (IoT) is the network of physical objects that contain embedded technology to communicate and feel or interact with their internal states or the external environment, characterized by (Iancu et al., 2020): things designed to be connected, volumes of communication, information action/ intelligence (information processed from communicated data/volumes of data), action (consequence of actionable information) and ecosystem.

\section{Influence of national defense by new technologies}

The competition between the great military powers in the field of the most sophisticated technologies has led to the unprecedented influence of the national defense capacity (Iancu et al., 2020). At the same time, the emergence and proliferation of emerging and disruptive military technologies determine new forms of manifestation of threats to national security and defense, to which an adequate response must be given. As access to emerging and disruptive military technologies increases, terrorism will exacerbate and continue to pose an unprecedented threat to national security. The political non-accountability of the new arms race will lead to uncontrolled access to new emerging and disruptive military technologies by various state and non-state actors.

New emerging and disruptive technologies will greatly influence the political-military factor in the field of military affairs. The pressure on the need to ensure increasing economic and financial resources will be amplified, with consequences on prioritizing the approach to the objectives to be achieved both at national and at NATO level. Also, new emerging and disruptive military technologies are leading to the reconfiguration of force structures to be able to use these technologies. In order not to spend exorbitant amounts of money on the import of emerging and disruptive military technologies, state entities must review their research structures and their own production capacities for defense in order to adapt to the structures of the profit market.

Military analysts estimate that by 2040, the human resource of defense will consist of members of the "digital natives" generation, also called "Generation Z", which will no longer differentiate between real and virtual life, do not value salaries but rather a coherent and transparent career that does not take into account financial interests. 


\section{Conclusions}

The technological transformations of the next 20 years will produce special mutations in the design and conduct of the war of the future, where a special emphasis will be placed on shaping the scenarios of the ultra-technological war. Although the total automation of the means of war is a lasting one, it still seems unethical to replace man with the ultra-sophisticated technology of the future, that is, it would not be appropriate to have firing should become the exclusive prerogative of an intelligent machine. The evolution of technological cooperation formats and programs will require the creation of new military alliances, in order to bear the burden of financial expenditures more easily.

\section{REFERENCES}

Eremia, C., \& Negoiță, S.V. (2021). I2DS2 Report. Tehnologii militare și duale. Proliferare, tranzacții. Available at: https://a2fc1d44-3535-41ef-b81b-fd8249528a46. filesusr.com/ugd/09931c 041a948e91f64fb89cb5c9268cf72c92.pdf, accessed on 16 July 2021.

Huza, A.A. (2021). Rusia are arma supremă: Racheta hipersonică Zircon este fără egal în lume. Available at: https://www.stiripesurse.ro/video-rusia-are-arma-suprema-rachetahipersonica-zircon-este-fara-egal-in-lume 1902594.htm, accessed on 28 July 2021.

Iancu, N. (2019). Noul dicționar al apărării: Tehnologiile disruptive. Monitorul Apărării și Securității, available at: https://monitorulapararii.ro/noul-dictionar-al-aparariitehnologiile-disruptive-1-21024, accessed on 16 July 2021.

Iancu, N., Dănilă, Ș., Oprea, Ș., Eremia, C., \& Dincovici, C. (2020). 2/I2DS2 Report. Influența tehnologiilor emergente și disruptive asupra organizării și întrebuințării forțelor armate. Asociația "Soluții integrate de securitate, apărare și intelligence", available at: https://www.i2ds2.org/raport-2, accessed on 16 July 2021.

Lupițu, R. (2020). Mircea Geoană, președinte al Board-ului pentru inovare din cadrul NATO: Păstrăm nealterată supremația tehnologică a Alianței. Available at: https://www.caleaeuropeana.ro/mircea-geoana-presedintele-board-ului-pentru-inovare-dincadrul-nato-trebuie-sa-pastram-nealterata-suprematia-tehnologica-a-aliantei/, accessed on 16 July 2021. 